\title{
Research on Undergraduate Students' Usage Satisfaction of Mobile Learning
}

\author{
Chun Mao \\ School of Journalism and Communication, Southwest University, Chongqing, China \\ Email: maochun1981@hotmail.com
}

Received 15 March 2014; revised 15 April 2014; accepted 22 April 2014

Copyright (C) 2014 by author and Scientific Research Publishing Inc.

This work is licensed under the Creative Commons Attribution International License (CC BY). http://creativecommons.org/licenses/by/4.0/

(c) ()

\begin{abstract}
This research focuses on the usage satisfaction of mobile learning among undergraduate students, and adopts the structure of close-ended and the Likert-Scale five-point measure questionnaire. There are 300 respondents from Southwest University. The questionnaires are randomly delivered to students from different majors and grades. The result indicates: 1) most of the undergraduate students are satisfied with mobile learning (76\%) and will use mobile learning in future learning (84\%). 2) More than half of the respondents have benefited from mobile learning, especially in quickly solving problems encountered in learning and making better use of learning time. 3) Undergraduate students are satisfied with the text content and image content in mobile learning, but the video content gets few agreements (11.4\%). 4) The item "I am satisfied with the mobile learning resources provided by my university" gets the lowest mean score $(M=2.15)$, so teachers and universities should pay more energy and effort to promote the quality of mobile learning resources.
\end{abstract}

\section{Keywords}

Mobile Learning, M-Learning, Satisfaction, Undergraduate Students

\section{Introduction}

Mobile learning (or m-learning), which means learning through mobile devices (such as smart mobile phones, tablet PCs and E-ink Book devices), is changing the education landscape by offering learners the opportunity to engage in asynchronous, ubiquitous instruction (Hyman, 2014). In the past ten years, great strides have been made in investigating the learning platforms and learning processes involved in mobile learning. Many researches claimed that adopting mobile technologies in higher education could create powerful opportunities to access information anytime and anywhere to perform authentic activities in the context of students' learning (Wesam, 2013; Martin, 2013). 
Research on mobile leaning in China began in 2000, introduced by Dr. Desmond Keegan. Now, mobile leaning is gradually becoming a research field with multidisciplinary participation, cross-field and multi-topic integration, as well as a key issue in the field of educational technology (Wang \& Wang, 2013). While there are a lot of mobile learning systems being developed, motivational factors and usage intent relating to mobile learning have been investigated (Ciampa, 2014; Hashim, 2014; Zhang \& Huang, 2013). There is no research on learner expectations and usage satisfaction of mobile learning in China.

\section{Methodology}

\subsection{Instrument}

This study focuses on the usage satisfaction of mobile learning among undergraduate students, and is quantitative in nature, and a developed instrument (questionnaire) was used to collect the data needed. This study adopts the structure of close-ended and the Likert-Scale five-point measure questionnaire. Each item is given a 5-point scale with 1 = strongly disagree, $2=$ disagree, $3=$ slightly agree, $4=$ agree, and $5=$ strongly agree. Each questionnaire took 20 - 25 minutes to complete. The questionnaire was developed in Chinese.

\subsection{Participants}

We chose 300 undergraduate students as the respondents. All of them came from Southwest University. The questionnaires were randomly delivered to students from different majors and grades.

\subsection{Data Collection}

Data for the research were collected for 2 weeks. We recalled 291 questionnaires, and selected the effective questionnaires according with the following criteria. 1) The respondents have used mobile learning; 2) all of the questions are answered; 3) there is no inconsistent answer. After rejecting invalid questionnaires, there are 263 questionnaires available.

\section{Results}

\subsection{Descriptive Statistics}

The descriptive statistics of the respondents are shown in Table 1 . All of the respondents have smart mobile phone, small part of them (24.7\%) have tablet PC (e.g. iPad, Galaxy Tab, Lenovo Pad), and only 5.32\% of the respondents use E-ink Book (e.g. Kindle, HanWang, BamBook). This means that smart mobile phone is probably the primary device in mobile learning, so the mobile learning content should been adapt to the small screen reading and learning. At the same time, constant vigilance is necessary in order to avoid eye injuries and the potential threats to the health.

Table 1. Descriptive statistics of the respondents.

\begin{tabular}{cccc}
\hline Items & Options & $\begin{array}{c}\text { Number of people } \\
\text { (the total is 263) }\end{array}$ & $\begin{array}{c}\text { Percentage } \\
\text { (the total is 263) }\end{array}$ \\
\hline \multirow{2}{*}{ Gender } & Male & 139 & $52.85 \%$ \\
& Female & 124 & $47.15 \%$ \\
Mobile devices & Smart mobile phone & & $100.00 \%$ \\
& Tablet PC & 263 & $24.71 \%$ \\
& E-ink Book & 65 & $5.32 \%$ \\
Using frequency of & & 14 & $11.41 \%$ \\
mobile learning & Several times per day & 30 & $32.32 \%$ \\
& 1 time per day & 85 & $40.68 \%$ \\
& 1 time per week & 107 & $14.07 \%$ \\
\end{tabular}


According to the item "using frequency of mobile learning", mobile learning is becoming more and more widespread among undergraduate students. There are 4 respondents (only 1.52\%) use mobile learning less than 1 time per month. Most of the respondents (more than 84\%) use mobile learning 1 time per week and even more. Especially, 30 respondents (11.41\%) use mobile learning several times per day.

\subsection{Satisfaction of Mobile Learning among Undergraduate Students}

Table 2 displays the results of statements regarding factors affecting satisfaction of mobile learning among undergraduate students. There are 12 items, and the mean score for each item was used to describe the strength of each item. There are 10 items' mean scores higher than 3, furthermore, 2 items' mean scores higher than 4 . On the other hand, there are 2 items' mean scores lower than 3 . The item "I will use mobile learning in my future learning" recorded the highest mean score $(\mathrm{M}=4.35)$. The second highest mean score is "Learning with mobile devices is pleasant" ( $\mathrm{M}=4.01)$, followed by "Mobile learning enables me to make better use of my learning time" ( $M=3.64)$ and "I am satisfied with the text content in mobile learning" $(M=3.62)$. The lowest mean score is item "I am satisfied with the mobile learning resources provided by my university" $(M=2.15)$. The second lowest mean score is "I am satisfied with the video content in mobile learning" ( $M=2.30)$.

\section{Discussion}

Based on the results obtained above, most of the undergraduate students are satisfied with mobile learning and will use mobile learning in future learning. Only $7.3 \%$ of the respondents disagree with the item "Learning with mobile devices is pleasant” (2.7\% strongly disagree, $4.6 \%$ disagree). In contrast, $76 \%$ of the respondents disagree with the item "Learning with mobile devices is pleasant" $(\mathrm{M}=4.01)$. At the same time, more than $84 \%$ of the respondents agree with "I will use mobile learning in my future learning", and this item recorded the highest

Table 2. Percentage distribution of satisfaction of mobile learning.

\begin{tabular}{|c|c|c|c|c|c|c|}
\hline Item & $\begin{array}{c}\text { Strongly } \\
\text { disagree (\%) }\end{array}$ & Disagree (\%) & $\begin{array}{l}\text { Slightly } \\
\text { agree (\%) }\end{array}$ & Agree (\%) & $\begin{array}{l}\text { Strongly } \\
\text { agree (\%) }\end{array}$ & Mean \\
\hline $\begin{array}{l}\text { Mobile learning enables me to quickly } \\
\text { solve problems encountered in learning. }\end{array}$ & $\begin{array}{l}18 \\
6.8 \%\end{array}$ & $\begin{array}{c}31 \\
11.8 \%\end{array}$ & $\begin{array}{c}69 \\
26.2 \%\end{array}$ & $\begin{array}{c}92 \\
35.0 \%\end{array}$ & $\begin{array}{c}53 \\
20.2 \%\end{array}$ & 3.50 \\
\hline $\begin{array}{l}\text { Mobile learning enables me } \\
\text { to make better use of my learning time. }\end{array}$ & $\begin{array}{c}10 \\
3.8 \%\end{array}$ & $\begin{array}{c}21 \\
8.0 \%\end{array}$ & $\begin{array}{c}88 \\
33.5 \%\end{array}$ & $\begin{array}{c}79 \\
30.0 \%\end{array}$ & $\begin{array}{c}65 \\
24.7 \%\end{array}$ & 3.64 \\
\hline $\begin{array}{l}\text { Mobile learning enables me } \\
\text { to learn more knowledge. }\end{array}$ & $\begin{array}{c}12 \\
4.6 \%\end{array}$ & $\begin{array}{c}41 \\
15.6 \%\end{array}$ & $\begin{array}{c}117 \\
44.5 \%\end{array}$ & $\begin{array}{c}67 \\
25.5 \%\end{array}$ & $\begin{array}{c}26 \\
9.9 \%\end{array}$ & 3.21 \\
\hline $\begin{array}{l}\text { Learning with mobile devices } \\
\text { is pleasant. }\end{array}$ & $\begin{array}{l}7 \\
2.7 \%\end{array}$ & $\begin{array}{c}12 \\
4.6 \%\end{array}$ & $\begin{array}{c}44 \\
16.7 \%\end{array}$ & $\begin{array}{c}109 \\
41.4 \%\end{array}$ & $\begin{array}{c}91 \\
34.6 \%\end{array}$ & 4.01 \\
\hline $\begin{array}{l}\text { I am satisfied with the text } \\
\text { content in mobile learning. }\end{array}$ & $\begin{array}{c}8 \\
3.0 \%\end{array}$ & $\begin{array}{c}32 \\
12.2 \%\end{array}$ & $\begin{array}{c}69 \\
26.2 \%\end{array}$ & $\begin{array}{c}97 \\
36.9 \%\end{array}$ & $\begin{array}{c}57 \\
21.7 \%\end{array}$ & 3.62 \\
\hline $\begin{array}{l}\text { I am satisfied with the image } \\
\text { content in mobile learning. }\end{array}$ & $\begin{array}{c}14 \\
5.3 \%\end{array}$ & $\begin{array}{c}38 \\
14.4 \%\end{array}$ & $\begin{array}{c}77 \\
29.3 \%\end{array}$ & $\begin{array}{c}83 \\
31.6 \%\end{array}$ & $\begin{array}{c}51 \\
19.4 \%\end{array}$ & 3.45 \\
\hline $\begin{array}{l}\text { I am satisfied with the video } \\
\text { content in mobile learning. }\end{array}$ & $\begin{array}{c}65 \\
24.7 \%\end{array}$ & $\begin{array}{c}93 \\
35.4 \%\end{array}$ & $\begin{array}{c}75 \\
28.5 \%\end{array}$ & $\begin{array}{c}22 \\
8.4 \%\end{array}$ & $\begin{array}{c}8 \\
3.0 \%\end{array}$ & 2.30 \\
\hline $\begin{array}{l}\text { I can access the digital library of my } \\
\text { university through mobile devices. }\end{array}$ & $\begin{array}{c}16 \\
6.1 \%\end{array}$ & $\begin{array}{c}30 \\
11.4 \%\end{array}$ & $\begin{array}{c}134 \\
51.0 \%\end{array}$ & $\begin{array}{c}68 \\
25.9 \%\end{array}$ & $\begin{array}{c}15 \\
5.7 \%\end{array}$ & 3.14 \\
\hline $\begin{array}{l}\text { I can access the online courses of my } \\
\text { university through mobile devices. }\end{array}$ & $\begin{array}{c}12 \\
4.6 \%\end{array}$ & $\begin{array}{c}33 \\
12.5 \%\end{array}$ & $\begin{array}{c}87 \\
33.1 \%\end{array}$ & $\begin{array}{c}68 \\
25.9 \%\end{array}$ & $\begin{array}{c}63 \\
24.0 \%\end{array}$ & 3.52 \\
\hline $\begin{array}{l}\text { I am satisfied with the mobile learning } \\
\text { resources provided by my university. }\end{array}$ & $\begin{array}{c}91 \\
34.6 \%\end{array}$ & $\begin{array}{c}84 \\
31.9 \%\end{array}$ & $\begin{array}{c}56 \\
21.3 \%\end{array}$ & $\begin{array}{c}21 \\
8.0 \%\end{array}$ & $\begin{array}{c}11 \\
4.2 \%\end{array}$ & 2.15 \\
\hline $\begin{array}{l}\text { I will use mobile learning } \\
\text { in my future learning. }\end{array}$ & $\begin{array}{c}0 \\
0.0 \%\end{array}$ & $\begin{array}{c}8 \\
3.0 \%\end{array}$ & $\begin{array}{c}32 \\
12.2 \%\end{array}$ & $\begin{array}{c}84 \\
31.9 \%\end{array}$ & $\begin{array}{c}139 \\
52.9 \%\end{array}$ & 4.35 \\
\hline
\end{tabular}

In this table, there are 263 questionnaires available, each item is given a 5 -point scale with $1=$ strongly disagree, $2=$ disagree, $3=$ slightly agree, $4=$ agree, and 5 = strongly agree. 
mean score in this research $(\mathrm{M}=4.35)$. This is because that most of the undergraduate students are post-90's generation and are digital native. They had born in the era of computer, growing up in the internet age, using mobile devices every day. They are apt to accept new information technology and use it to improve learning naturally.

In addition, mobile learning is good for undergraduate students' study. Most of the respondents have benefited from mobile learning. More than 55\% of the respondents agree with the item "Mobile learning enables me to quickly solve problems encountered in learning" $(M=3.50)$, and more than $54 \%$ of the respondents agree with the item "Mobile learning enables me to make better use of my learning time" ( $M=3.64)$. With the help of mobile devices, undergraduate students are able to study anywhere and at any time. When meet with difficulties, they could find information or ask teachers for help through mobile devices immediately. Moreover, undergraduate students could use fragment times, such as bus time, queuing time or boring time, to read and learn more.

The results also show that undergraduate students are satisfied with the text content and image content in mobile learning. The mean score of item "I am satisfied with the text content in mobile learning" is 3.62, and the mean score of item "I am satisfied with the image content in mobile learning" is 3.45. Over half of the respondents agree with both of the two items (58.6\%, 51.0\%). Conversely, only $11.4 \%$ of the respondents agree with the item "I am satisfied with the video content in mobile learning" ( $3.0 \%$ strongly agree, $8.4 \%$ agree, $\mathrm{M}=2.30$ ). Text and image content can have better display on small screen used by mobile devices, and have fewer network flows than video content. Furthermore, text or image reading could be interrupted at any time, more suitable for fragment learning. In order to improve the user satisfaction of video learning content, we should reduce the length of video and split long video into small segmentations in the light of basic subject knowledge.

Meanwhile, although "I can access the digital library of my university through mobile devices" $(\mathrm{M}=3.14)$ and "I can access the online courses of my university through mobile devices" ( $M=3.52)$ have acceptable mean score, more than $66.5 \%$ of the respondents disagree with the item "I am satisfied with the mobile learning resources provided by my university" (34.6\% strongly disagree, $31.9 \%$ disagree, $M=2.15$ ). This can be viewed from two sides. On one hand, teachers and universities should pay more energy and effort to promote the quality of mobile learning resources. On the other hand, undergraduate students are eager for better resources and they want to learn more from mobile learning.

\section{Conclusion}

Although undergraduate students are not satisfied with the mobile learning resources and the video content in mobile learning, the overall satisfaction of mobile learning among undergraduate students is considered high, based on the high mean scores recorded for all the statements included in the questionnaires. More than $80 \%$ of the mean scores of all items included in the questionnaire are higher than 3. Especially, most of the students incline to use mobile learning in future, based on the highest mean score in this research is about mobile learning use intention. The Education Informatization Ten Year Development Plan (2011-2020) released by the Ministry of Education of the People's Republic of China, claims that informatization is an effective way to improve the quality of higher education. We suggest that teachers and schools should encourage and motivate students to use mobile learning, initiate and work on quality improvement projects to promote the learning effect of mobile learning.

\section{Funding}

Supported by “the Fundamental Research Funds for the Central Universities” SWU0909645.

\section{References}

Ciampa, K. (2014). Learning in a Mobile Age: An Investigation of Student Motivation. Journal of Computer Assisted Learning, 30, 82-96. http://dx.doi.org/10.1111/jcal.12036

Hashim, K. F., Tan, F. B., \& Rashid, A. (2014). Adult Learners’ Intention to Adopt Mobile Learning: A Motivational Perspective. British Journal of Educational Technology. http://dx.doi.org/10.1111/bjet.12148

Hyman, J. A., Moser, M. T., \& Segala, L. N. (2014). Electronic Reading and Digital Library Technologies: Understanding Learner Expectation and Usage Intent for Mobile Learning. Educational Technology Research and Development, 62, 3552. http://dx.doi.org/10.1007/s11423-013-9330-5

Martin, F., \& Ertzberger, J. (2013). Here and Now Mobile Learning: An Experimental Study on the Use of Mobile Technol- 
ogy. Computers \& Education, 68, 76-85. http://dx.doi.org/10.1016/j.compedu.2013.04.021

Wang, Y. M., \& Wang, J. (2013). Research Status and Future Trends of China’s Mobile Learning in Recent 20 Years. Modern Distance Education Research, 10, 49-55.

Wesam, S., Gail, H., Elizabeth, F. G., \& Colin, H. (2013). Supporting Interaction in Learning Activities Using Mobile Devices in Higher Education. 12th World Conference on Mobile and Contextual Learning (mLearn 2013), $2013,35$.

Zhang, L.-L., \& Huang, R. M. (2013). A Critical Analysis of Environment Designing for Mobile Learning. Modern Educational Technology, 23, 115-119. 